\title{
ONLINE MEDIA AND ESTABLISHMENT OF STUDENTS' RELIGIOUS UNDERSTANDING IN MADRASAH ALIYAH KENDARI CITY
}

\author{
Paisal \\ Balai Penelitian dan Pengembangan Agama Makassar \\ Jl. AP. Pettarani No.72 Makassar \\ Email:umar.faisal@rocketmail.com
}

Article received March 28 ${ }^{\text {th }}, 2021$; Article revised May 1 $1^{\text {st }}, 2021$; Article approved May $8^{\text {th }}, 2021$

\begin{abstract}
This study used a qualitative descriptive method with research problems: How do Madrasah Aliyah students practice religious discourse from online media in their daily lives?, and how do teachers respond and align the religious understanding of Madrasah Aliyah students who interact with the religious discourse from online media?. The research location was in Kendari City, Southeast Sulawesi. The informants were 25 students at MAN 1 Kendari and MAS Ummushabri. The research results found that Madrasah Aliyah students are quite active in accessing religious preaching content using online social media platforms. The online media that is most accessed and used for religious content are Instagram and YouTube in the form of audio-visual videos. The rest are interested in reading status and articles considered to be in line with their understanding. Some of the students follow several popular preachers who are actively spreading religious content on social media. Influenced by online media, some students questioned and challenged the basis of the country, religious traditions, and local traditions addressed to their teachers, families, and relatives. In daily behavior, there is a positive side. Students are more diligent in worshiping and assembling in the Mosque. Madrasah and teachers have issued several protective policies to protect students from easily exposed to radical ideology. The responses and policies include limiting the use of cellphones in schools, intensive religious guidance provided by the teacher, protecting outside groups from entering and providing religious guidance to students, and enrich learning material with religious moderation content on a limited scale.
\end{abstract}

Keywords: online media, religious understanding, madrasah aliyah kendari

\section{INTRODUCTION}

$\mathrm{T}$ he industrial revolution 4.0 has brought major changes in the learning system, including religious studies. The emergence of various learning-based online sites has slowly shifted the role of teachers in schools. Neil Postman's concern about the end of education (after the advent of television) has become increasingly apparent.

The largest online media users in Indonesia are generation $\mathrm{Z}$, popularly known as the millennial generation. We can be sure that online network (internet) users also have social media accounts. At the National Coordination Meeting held by The Ministry of Religious Affairs in early 2019, Inayah Wahid as a speaker said that the religious characteristics of the millennial generation are function-based, not figures. They don't care about who speaks but whether the speech fits with their interests.
In mass media, communication (print and online) is the most effective medium for publication and ideology dissemination. According to Eriyanto (2005: 13), the text is a form of ideological practice. Language, writing, diction, and grammatical structures are understood as choices to transmit certain ideological meanings to win public support. Religious (Islamic) discourse is constructed in such a way based on the ideology of the announcer. Therefore, the battle of discourse in the media is inevitable, and one of the most effective media is a network-based social media channel.

One of the international terrorist organizations appalling the world is ISIS. In spreading its ideology, ISIS uses social media channels including Telegram, Twitter, Whatsapp, Instagram, and Facebook. Inevitably, this propaganda carried out through online media has received a lot of sympathies. However, not a few are tempted by the lure of 
an Islamic State that is promised to improve the welfare of all its people. At first, many parties in Indonesia declared their support, and there were some people and even families who joined Syria and Iraq. An act influenced by social media that they later regret.

The increasing number of social media users now become the easy target for disseminating certain religious doctrines. Research in the last few years showed that social media users had increased sharply. Based on the findings of Wearesocial Hootsuite's research released in January 2019, social media users in Indonesia reached 150 million people or $56 \%$ of the total population. Meanwhile, mobile social media users (mobile phones, gadgets, smartphones) reached 130 million people, or around $48 \%$ of the population of 268.2 million.

Based on the research results by the Indonesian Internet Service Providers Association (APJII) in 2018, internet users were 171.17 million people. Polling involved 5,900 samples with $1, .28 \%$ margin of error. The poll found out that $71.8 \%$ of students were internet users. Most internet users were in the age group with the details; age group of 10-14 years old are $66.2 \%$, the rest who do not use are $33.8 \%$; the age group 15-19 were reaching $91 \%$, the age group 20-24 were $88.5 \%$. Meanwhile, the second largest number of users were 20-24 years old, even children aged 5-9 years used the internet, reaching $25.2 \%$ of the total sample. Even in another study that $91 \%$ of internet users use it for social media.

In 2015, the Makassar Research and Development Agency for Religion researched the Shifting of Students' Religious Idea, which found a change in the pattern of religious discourse formation, which was influenced by social media (Paisal, Research Report on page 38). In the research, it was also found that several students who became HTI activists who started when they were in high school had accessed religious content on the internet since they were still high school students.

Another research that was conducted by the Makassar Research and Development Agency for Religion in 2016 was related to radicalism among students. From the research findings, it was revealed that there were hundreds of high school students who were willing to commit suicide bombings in the name of religion. For example, in Kendari, 4 people of 220 samples were very willing, and 17 students were willing. In another question from the quantitative research, all students who became respondents had social media accounts.

Several national research results also show similar symptoms that online media currently shape students' religious understanding. Abundant data sources and cheap and easy access make students happy to interact with the virtual world. Consumption of a variety of religious sites will form diverse understandings. This has positive and negative implications. If students consume sites that teach religious moderation, they will understand religious moderation that will build students' reasoning and vice versa.

The concern is when students intensively consume destructive and closeminded religious understanding. It will form a destructive and close-minded generation. This is certainly not good for nation and state living.

Based on the explanation above, this research report was trying to see the impact of social media in the religious studies of Madrasah Aliyah students in Eastern Indonesia. This is related to the context of the development of religious life in Indonesia through the path that the Indonesian Ministry of Religious Affairs has declared.

This study determines the influence of social media on religious studies and its influence on the formation of students' religious understanding, which is formulated in several research questions: a) How do Madrasah Aliyah students practice religious discourse received through online media in their daily life?; b) How do the teachers respond and align the religious understanding of Madrasah Aliyah students who interact with religious sites through online media?

In this research, online media is widely used to refer to being connected to an internet connection or "in the network" (online). According to KBBI V (Online Application), online is "connected via computer networks, the internet and so on". Meanwhile, online media is internet-based media that may contain news, texts, videos, photos, or sounds. According to Ashadi Siregar (Agung Kurniawan. 2005: Page 20), online media is defined as a general term for 
media based on telecommunications and multimedia (computers and the internet). It contains a portal, website, radio-online, TVonline, online press, mail-online, and others with its characteristics and facilities that allow the user to use it. The open characteristics of the internet network allow everyone to create their own media. Examples of online media are news sites, kompas.com, detik.com, babe, viva.com. Fajar.co.id., NUonline.com. Muhammadiyah.or.id. It also can be in a more open blogspot or kompasiana.

Social media (socmed) is an onlinebased media loads and shares various types of content, including religious preaching content. In KBBI V (online application, 2018), Social Media is defined as "a page or application that allows users to create and share content or be involved in social networks." The difference between online media and social media is simply that "social media is an open part of online and anyone can create their own account, while online media is mostly used to refer to news sites, pages, or portals." Currently, the most widely used social media are Whatsapp, Facebook, Instagram, Twitter, Telegram, Youtube, etc.

In this research, Religious Understanding is known as religious knowledge, attitudes, and /or behaviors embraced or believed by students, influenced by religious content accessed from social media.

Religious understanding in the context of this research is a change in the way the Islamic community understands religion from tasammuh (tolerant), tawasuth (not extreme), respecting tradition, appreciating ulama and love of the homeland to being extreme, intolerant, closed, disrespecting tradition, and not considering the importance of the homeland (nation-state) which is summarized in the word "religious moderation" (see Research and Development Agency of the Ministry of Religious Affairs: 2019. Page 15).

It is alleged that the formation of instant and sometimes excessive religious understanding (tatharruf or extreme, radical) is obtained through information and preaching on online network-based social media.

The increase of easy access to social media nowadays makes it easier for the public to communicate and share information. As a result, media has been developed from old media (print and television) which are one-way communication to new media (online). McQuail (2011: 74) described the characteristics of old media and new media: 1 ). The old media has the concept of one object talking to many people, while the new media is decentralized, everyone has the opportunity to speak to anyone. 2). Old media is one-way communication, while new media is two-way communication allowing feedback from the audience. 3). The old media is under State control, while the new media is not controlled by the State and can even be enjoyed by anyone without state restrictions. 4). The old media produces social strata, while the new media is producing the concept of democratization. 5). The old media fragmented the audience, while the new media put the audience in an equal position.

As an effort to determine the influence of online media on the establishment of religious ideology, researchers intensively explore the sites, pages, or online media that students access. A structured media generally has its own ideology. According to Eriyanto (2005: 13), the text is a form of ideological practice, language, writing, choice of words, and grammatical structures are understood as choices expressed to transmit certain ideological meanings to win public support. Religious (Islamic) discourse is constructed in such a way based on the ideology of the announcers. Therefore, the battle of discourse in the media is unavoidable. One of the most effective media is online media channels.

The public gets information through newspapers, magazines, bulletin, and now online media. Audiences in literal meaning are also referred to as public. Sugeng Pujileksono (2015: pp. 163-164) described various types of audiences. Audiences utilizing the bulletin, daily news, magazines, education, and entertainment are referred to as readers. Audiences using radio as a medium to obtain information, education, and entertainment are called listeners. The audiences using film/television as a medium for obtaining information, education, and entertainment are called the viewers. Finally, audiences using the internet to get information, education, and entertainment are called users. In the context of this research, the phenomenon of using 
online media to access information continues to grow from text to audio-visual. The tendency to use visual media is a massively encountered trend. The most accessed media are Youtube, Instagram, and Facebook.

In recent years, a study called digital sociology has been developed. As a result, the behavior of online social media users could be examined by tracing their activities in cyberspace. It used various approaches to determine the use of digital media by audiences both qualitatively and quantitatively. Data were analyzed from interviews and also observed interactions and posts on online social media.

Deborah Lupton emphasizes the concept of digital sociology in 4 ways: 1). Professional digital practice using digital tools as part of the sociological practice - to build networks, construct an online profile, publicize, share research, and instruct students; 2). Digital technology analyses researching the ways in which people's use of digital technologies configure their sense of self, their embodiment, and their social relations, and the role of digital media in the creation or reproduction of social institutions and social structures; 3) Digital data analysis using naturally occurring digital data for social research, either quantitative or qualitative; and 4). Critical digital sociology undertaking reflective analysis of digital technologies informed by social and cultural theory (Lupton, 2015: Pg 15-16).

\section{RESEARCH METHOD}

This research used qualitative methods. This method was used to explore data by conducting interviews with selected informants (purposive sampling). From the initial informants, other competent informants were obtained. These informants were considered to represent the research topic. There were two types of informants in this context. The first was those who understand social media issues and religious understanding among students. They could be intellectuals, academics, teachers, or principals. The second type of informants was students who were active in student organizations. This research was conducted by targeting the students in MAN 1 Kendari and MAS Ummushabri.
Since this study identified the patterns of online media accessed by these students and explored how the establishment of their religious understanding occurs, the interview technique relied more on unstructured interviews adapted to the informants' conditions. In the interview, the researcher was expected to find out what social media students use most intensively in accessing religious content and the religious sites, pages, or fan pages that are most frequently visited.

In addition, to help search data, researchers did initial observations. Initial observations aimed to determine the target schools, including public and private senior secondary schools under the auspices of the Ministry of Religion. Observations were also carried out to determine students' religious behavior or practices in daily life.

Data analysis was performed using a descriptive model, describing the detail of the existing data from the field in an emic and ethical manner. Previously, data were grouped and categorized according to existing data categories.

Data processing and analysis were carried out by examining all available data from various sources, including interviews, field notes, documents, pictures, photos, etc. Then data were reduced, arranged into units, and categorized. The next process was constructing relationships between categories, then arranged them in descriptive writing. The data were presented with a critical-descriptive approach.

\section{DISCUSSION}

\section{The Influence of Online Media on Religious Understanding of Students in Madrasah Aliyah}

This research was conducted at MAN 1 Kendari and MAS Ummushabri, located in the center of Kendari City. Kendari City is the capital of Southeast Sulawesi Province. The area is located in the Southeast of Sulawesi Island around Kendari Bay. There is one island in Kendari City which is known as Bungkutoko Island. The land area of Kendari City is $269.363 \mathrm{~km} 2$ or $0.70 \%$ of the land area of Southeast Sulawesi. Kendari City has the boundaries of the North-Konawe Regency; East-Kendari Sea; South-South Konawe Regency; West-South Konawe Regency. 
Muslims predominantly inhabit all sub-districts in Kendari City, both native Tolaki and Muslim immigrants from Muna, Bugis, Makassar, Ternate, Java, etc. The total population is 263.858 . Islam is the majority religion with 246.478 adherents, 7.404 Christians, 5.955 Catholics, 1.509 Hindus, and 866 Buddhists, while Confucianism which has been officially recognized as a religion, is not included in this data (Ministry of Religion 2020). This data shows that the number of Muslims in Kendari City as the capital of Southeast Sulawesi province reaches 93\% of the total population. This shows that the development of Islam in Kendari City is quite dynamic and fast (Muslim, 2017: 25-42).

Kendari, as a developing city with a growing population, continues to improve. As the provincial capital with various mining companies and smelters scattered in various districts, Kendari is a city that is busy with migrants. Because of this, this city continues to improve in providing various shopping center facilities, tourist attractions, entertainment venues, and hangout places, such as cafes and coffee shops scattered in almost every corner of the city. Quite a lot of exclusive SPA and karaoke services are also available. It is common to find young people relaxing in the center of the crowd, in cafes and shopping centers, adult men relaxing at the coffee shop with their colleagues with free wifi access to stay online connected to the internet network.

The interaction between various ethnicities and religions occurs in social spaces, which has been going on for a long time. Muayyad (45), a Bugis man who now lives in Kendari, said that he had made friends from various groups of various ethnicities and religions to become business colleagues from coffee shops. There are many coffee shops crowded with visitors, and usually, when they are comfortable in the coffee shop, they will become the regular customers and make it an appointment location.

As for school-age teenagers, they prefer to visit cafes that look more modern, luxurious, and up-to-date. In addition to providing various types of food and drinks for teenagers, the cafe is equipped with facilities for free wifi access to live music. For adolescents, wifi facilities are important considering the limitations of internet quota data pulses given by parents. Wifi facilities are widely used to download applications, songs, and even video content.

In today's digital era, all students are good at accessing online content, including Madrasah Aliyah students in Kendari City. The influence of online media inevitably makes students get involved in accessing the internet. Some students, while at home, can freely access the internet. Apart from social media, some students also play games and access online religious content.

In general, the social media that most students use are Instagram (IG), Whatsapp (WA), and Facebook (FB). Students also access online religious sites. The most watched religious lecture content is from Youtube, Instagram, and a small portion of it is watched from Facebook.

Several students at the two Madrasah Aliyah often access almanhaj.or.id. This site can be found easily by using the Google search engine. In the author's search using the keyword 'almanhaj.com' via Google, this site is directly loaded and is located at the very top with various types of content categories. This shows that this site is accessed quite often with the same keywords. This site contains various categories of Islamic religious content, from ahkam, fiqh, al-Masaail, the Al-Qur'an, science, alwajiz to actual issues, etc. With the motto "walk on the manhaj as Salafus Salih", the various contents on the site are in line with the salafi wahabi manhaj, who aggressively attack and proclaim different religious understandings and practices.

RAZ (a research participant) got to know such a site from posts that included links by his friends on FB. Since that time, RAZ, who was full of enthusiasm for "hijrah" and want to understand the correct way of Islam better, often visited the site in his spare time or needed reading. According to him, the site contains a lot of content according to a straight manhaj.

In his understanding, the surrounding community's traditions are contrary to Islamic teachings but are still carried out, for example, maulid, barzanji to kalosara (local traditions of the Konawe Tribe). However, he realized that he did not have sufficient knowledge, so he did not dare to prevent or take action against what 
he called deviations from religious teachings and was classified as polytheists.

Once in a classroom, he tried to ask questions in the study of the Al-Qur'an and Hadith about the law of maulid, but after being answered by his teacher, he no longer denied it. According to him, it was quite disappointing for many scholars who allowed bid'ah and even polytheism to occur in society. That is why he agreed with the idea of an Islamic State or caliphate so that all things that are contrary to the Al-Qur'an and Hadith can be eradicated.

His acquaintance with this site led him to various content in other media which he considered the same. He started watching lectures from Ustadz Yazid Jawwaz, Hanan Attaki, Syafiq Reza Basalamah, and Adi Hidayat on Youtube. He watched some on Instagram and Facebook shared by his friends and certain pages he followed. When watching television at home, he often watched Yufid TV, Rodja, and Muadz TV, several times with parents who said they were quite happy that their children watched religious lectures.

In the author's search on his personal Instagram, there are several video lectures of Adi Hidayat, Hanan Attaki, and Syafiq Reza Basalamah which he shared. According to him, the video was shared by his friend in WA, who then enthusiastically shared the video on his Instagram.

Although he admitted that he had not been able to practice all the teachings he conveyed, he tried to find out first because what was conveyed was in accordance with the Al-Qur'an and Hadith as for the matter of practice, it was carried out slowly. According to him, the conditions for accessing preaching media must be in accordance with the AlQur' an and hadith because many other media are misleading. RAZ is quite fluent in mentioning some of the names of ustadz or religious figures that he likes the most, namely Syekh Salih Al Fauzan, Syekh Abdul Aziz bin Baz, and Syekh Utsman al Khamis.

Similar to RAZ, AM (16), a student of MAN 1 Kendari who is in the spirit of emigrating likes to watch religious lectures on the YouTube channel. He subscribed to Adi Hidayat's channel and even added a notification bell to a new video post. In a channel that is managed professionally with attractive and contemporary images, it is only filled with videos of the ustadz's lecture known by the acronym UAH. AM even provided time to watch in the afternoon. AM downloaded and installed a special application that could easily download videos from unprotected YouTube channels. When he found an interesting video that was considered in accordance with the latest conditions, he would upload it on his personal Instagram. In addition to the UAH video, in his IG account there are several videos of Ustadz Firanda Andirja and Syafiq Reza Basalamah.

His enthusiasm to spread preaching was based on the message from the hadith which is often conveyed by preachers "even if it is only one verse". Although it was still limited, he considered it to be within his abilities as a student. The condition of the country which is considered unstable, and the influence of reading on social media where he found posts about the burning of the 'tauhid flag' made AM dream of a caliphate or an Islamic State. According to him, only Muslims have the most right to become leaders because Muslims are the most adherents of the religion in Indonesia.

Although having friends of different religions, AM refused to congratulate his friend's religious holiday because, according to him, it could damage his aqidah, as Ustadz Yazid and Syafiq Reza Basalamah often convey in videos he watched online. This was confirmed by the sermon of an ustadz who affiliated network of Muadz bin Jabal. However, he maintains a friendly relationship, still allowing friends of different religions to visit or wish him a happy Eid.

Two students, MR (16) and ALZ (17), are also in love with religious content on their social media pages. On Facebook, MR liked the Sunnah Remember and Bogor Mengaji groups/pages and followed each of their posts. MR idolized Khalid Basalamah, Ustad Yazid Abu Jawwaz, and Firanda Andirja. ALZ liked IG Gen Hijrah and idolized Taqy Malik and Felix Siauw as hijrah icons. Apart from IG, the two teenagers also watched videos of religious lectures from Youtube and read posts about what they called preaching in family group Whatsapp if anyone shared them. The two students also accessed media for religious preaching content from muslim.or.id and 
almanhaj. or.id. The influence of reading and watching made them want a state based on Islam or caliphate because they considered it in accordance with the Al-Qur' an and hadith.

Nevertheless, in their observations, the two girls admitted that they had not been able to apply all of these understandings. ALZ, as a Buginese daughter, her family still carries out typical Islamic traditions in the archipelago or Aswajah, such as the traditional maulid celebration, barzanji in every celebration, or tahlilan if a family dies. "In my heart, I often wonder why these bid'ah continue to be practiced, isn't that bid'ah sir, right? Because I can't argue with my parents." That is her confession.

Salafi Wahabi-preaching style, which is increasingly incessant through social media and online media, is difficult to contain and influences the establishment of an exclusive and anti-difference religious understanding. Generally, the media or channels use effective and contemporary communication strategies so that the younger generation favors them. Those who initially only watched video lectures, saw memes, or skimmed through social media then were further interested in visiting the websites they managed.

In social media, it can be seen how they manage and frame issues in such a way to attract enthusiasts. It can be seen, for example, from the issue of criminalization against ulama or injustice against Muslims and so on, which collides with fellow people or between mazhab. One example, from several posts on the Bogor Mengaji Facebook page that students followed and shared in their social media accounts, was clear that the anti-bid'ah campaign was confronted with the sunnah. It seems that the other groups are all ahlul bid'ah and they are experts in sunnah. The following is an excerpt from a post that appears from WAG:

Bismillah

WE ARE ISLAM, BUT OUR WAYS ARE DIFFERENT. The pillars of Islam and our pillars of faith are the same. Our mosques are the same.

Our holidays are the same.

We are both Muslims, but our paths are different.

I follow the guidance of the salafus righteous

While you follow the understanding of mass organizations and kyai,

I love the sunnah and leave bid'ah,

While you are leaving the sunnah and loving bid'ah,

I like to go to the science council,

While you prefer to go to malls and karaoke places.
I leave the culture if it is against the Shari'a,

Meanwhile, you still maintain the culture even though it is against the Shari'a.

I don't like wearing tight and sexy clothes, and I prefer wearing loose and covered clothes with my hijab syar'i/cadar,

Whereas you like to wear tight and sexy clothes, and you don't want to wear a hijab, so that your genitals will open and show.

I do not celebrate birthdays, do not like music, do not tahlillan deceased, do not go to shamans, do not recite blessings at the grave, do not give offerings, do not do isbal, do not tasyabbuh, do not shake hands other than mahrom,

While you are still doing the things above.

Oh, my brother...

I cannot force you to practice it because, in Islam, there is no compulsion.

I also can't change you so you can be like me,

Because my job is only to convey, while guidance belongs to Allah.

I do not judge that you are astray, you are wrong, you go to hell. But I'm just trying to practice and try to invite you to follow the right path, which is the path as the righteous shalafus practice and teach.

I'm not too fanatic about religion ...

I am not the holiest and self-righteous person ...

I'm also not one who is following a cult ...

But since I realized ..

That the salafus righteous that we must follow ...

That the world is not our place ...

That our age is so short ...

That the afterlife is very heavy ...

That I still have many shortcomings and sins ...

And because of all that, I am now trying to obey religion and learn to follow the understanding of the salafussalih as the best generation of this ummah.

And I hope that Allah will be pleased with the path I have taken so that I will be entered into His heaven.

May Allah guide you and me to follow the straight path, which is the path that Allah is pleased with, as the path that the Prophet Sallallaahu 'Alaihi Wasallam and the righteous shalafus taught.

Akhukum,

Abu Yahya Al Bustamy

$$
\begin{gathered}
\text { Reposted by: } 2 \text { Group Whatsapp manhaj salaf Channel } \\
\text { telegram salafyways " }
\end{gathered}
$$

The post was liked by many people and has been shared thousands of times. It seems implicit how clerics and mass organizations are clashed with what they call shalafusshalih. It described that as if kyai does not understand and does not rely on knowledge on salafusshalih scholars. In addition to aggressively criticizing religious practices or traditions, which according to them, the heresy of this FB page was also quite active in posting video lectures of Firanda Andirja, Yazid Abu Jawaz, Khalid Basalamah, and others who were related to their provocative methods of preaching, the video was also featured on TV Rodja in longer duration.

The distribution of the group's lecture content is very wide. According to the students who became informants, this was because they were firm in preaching, according to the Al-Qur'an and Sunnah, and did not make friends with infidels or were 
clearly fighting for Islam. No students know moderate scholars who are also active enough to share posts or videos of their lectures, such as Gus Baha (Kyai Bahauddin Nursalim), Gus Miftah, Gus Muwaviq, or Gus Nadirsyah Hosen. They also did not know Gusdur as a Kyai but as a former president who was blind, and some even considered Quraish Shihab heretical because his teachings and his family did not conform to Islam. They admitted that they had read this in a post on Facebook.

It must be admitted that the video lectures on the Youtube channel, which students much love, are indeed quite a lot watched. However, at least several things influence such conditions. First, it is clear that the YouTube channel is managed professionally. Second, the video display is not monotonously decorated with various attractive graphics. Third, the headlines are catchy. Fourth, video duration is short. Fifth, rhetoric speakers exploded, attacked, or even misled others who do not share the same understanding. Sixth, using terms that are popular with the public, generally Arabicrelated terms, such as Hijrah, Hijab, Akhi, etc.

In the search for the author of the website almanhaj.or.id related to muslim.or.id, alquran-sunnah.com, there are quite many the same articles uploaded by the website. Many personal blogs also post these articles on their pages. It seems clear that this channel has a connection by bringing the same ideology and religious understanding. Muslim.or.id. is a backup website and replaced eramuslim.com, which in 2015 was included in the Ministry of Communication and Informatics as one of the radical sites. Some content that is considered radical, such as support for ISIS and defense against terror bomb perpetrators, is no longer found on muslim.or.id.

The vigorous campaign regarding the obligation to uphold the caliphate was quite influential on students. In the initial questioning of 25 students, 22 people agreed with the caliphate state. When asked further why they wanted the caliphate to get various answers, some answered because they were in accordance with the Hadith and the Al-Qur'an, or because they were found in the study of Islamic Cultural History. Some answered because they have read it in their friends' status so that the Caliphate is the solution to all problems because this earth belongs to Allah and the prohibition of law besides Allah's law. The exposure to the same issue on an ongoing basis causes many to be captivated and believe it is an "Islamic truth" that must be fought.

In the context of Kendari City, the discourse on the caliphate from 2014 to 2016 was indeed quite massive, spreading on various social media platforms and in the real world. In those years, HTI intensified the campaign for Indonesia Belonging to Allah. The target was all groups, from elementary schools to tertiary institutions, from the pulpit to the pulpit, from recitation to recitation. In May 2015, HTI held a grand meeting and parade entitled "Together with the Ummah, uphold the Caliphate". According to the committee's claim, thousands of participants reached hundreds of thousands of "caliphate fighters" packed the ex-MTQ field in the city center. Participants came from various cities, young and old, to involve school children from elementary to tertiary (Paisal: 2016).

\section{Aligning Religious Understanding of Madrasah Aliyah Students}

MAS Ummushabri has a program to counteract the exclusive religious understanding of its students. According to Supriyanto (50), the program is an International Camp. In this program, students make visits to partner schools abroad. The schools include America, Thailand, Malaysia, and Philippines. On the other hand, MAS Ummushabri has received visits from the partner school's students at its Madrasah Aliyah. The Ummushabri International Camp (UIC) event was held in January 2020, which became an introduction to the culture of Southeast Sulawesi (Muslim, 2019: 211-224).

Apart from increasing the capacity to speak English, it also introduces the other countries' ethnicity, religion, and culture. MAS Ummushabri also involved an American English teacher, Mr. Robert and Miss Erin since 2017. The program is expected to make students more open to differences and not close themselves to other people of different religions.

As an Islamic religious institution, this program reaps pros and cons. Some teachers against it think that this violates religious teachings because it provides opportunities for 
other religions to enter the madrasah and is considered to damage students' aqidah. Supriyanto stated that this comes from narrow thinking that does not want to accept differences, and if it is instilled in students, it will be counterproductive to building tolerance in the students' minds. Respecting differences is not to destroy tauhid. On the contrary, excessive suspicion of other religions causes a lack of a culture of mutual respect. The coach and teacher who refused later resigned.

In other places, MAN 1 Kendari counteracts the influence of religious understanding and practice that is radical and contrary to the schools' rules and vision. For example, one of the rules is in the dress code. According to Ma'sud Sidik (head of MAN Kendari), this is done in coaching and uniformity. One example is the prohibition of wearing cadar. Several times, students who wear cadar must be instructed not to wear it at the madrasah. Some students had refused and even called their parents, but a rule cannot be broken if they do not agree. It is recommended to resign.

E-learning named Hybrid is implemented to increase the capacity to introduce information technology, especially in MAN 1 Kendari. Hybrid is defined as a class designed so that the learning system integrates/crosses various face-to-face learning activities with online learning (utilizing technology and the Internet). If there is a learning schedule using the internet media, it makes students quite free to use online devices at school, with school wifi facilities. In such time, students access online media or check their social media. However, in the teachers' monitoring, there were no students who had negative behavior on social media (Interview with Zul Rahmad, Deputy Principal, February 2020).

In the MAN 1 Kendari Mosque before the dissolution of HTI organizations, HTI cadres often delivered sermons. Now with this policy, mosque administrators are trying to be selective in choosing the preacher. It aims to avoid the influence of radical Islam in the madrasah. In addition, HTI cadres have tried to enter through the Taklim Council, which routinely conducts recitation when students perform Friday prayers at the Mosque. Now, majelis taklim preachers are more concerned with discussing women's fiqh.

Some students tried to ask about the caliphate during studying, why it was no longer enforced, why the caliphate collapsed, or didn't have hadiths and verses in the AlQur'an. It happened in the study of Islamic Cultural History taught by Mr. Nurdin (54). According to him, several years ago, some tried to ask questions and only stopped after being asked back, try to say the verse if there was one. It seems that HTI's ideology of the caliphate influenced these students. After that, Mr. Nurdin did not find many students eager to return to the Caliphate era, even though they might enjoy the caliphate model of government.

Teacher of Al-Quran Hadith Subject, Mrs. Aisyah (57), quite a lot found student questions related to bid'ah, for example in the maulid. According to her, some students asked about it after watching the anti-maulid lecture video. According to the ustadz, the maulid was never carried out in the time of the prophet, why should it be done now. Mrs. Aisyah explained that the maulid commemoration was carried out to get to know the Prophet Muhammad more, and more about the traditional food types to be eaten together. The decoration was to show joy over the birth of the Great Prophet. Tradition, according to her, is part of good al-Urf and can be implemented to decorate the implementation of the maulid.

Regarding the correct way of dressing, according to Mrs. Aisyah, as long as she has covered her genitals that the scholars agreed on, she is correct. Because of that, there is no need to try to appear different by bringing religious understanding which is not followed by many people around us. According to her, the use of cadar in Kendari City has started to become massive since the entry of several salafi groups. Previously, although various kinds of Islamic boarding schools had been established, residents could not find wearing cadar, even if they did, they were usually outsiders.

The tendency of students to be exclusive was clearly formed from the exposure to information on online social media they received. What is conveyed by Eriyanto (2005: 13) that the text is a form of ideological practice, language, writing, choice of words, 
and grammatical structures are understood as choices expressed to carry certain ideological meanings in the level of winning public support. Religious (Islamic) discourse is constructed in such a way based on the ideology of the preacher. The establishment of the desired religious ideology appears to be quite effective through social media channels and online media. Therefore, discourse wars in the media are unavoidable, and one of the most effective media is online media channels.

In instant online media with unlimited reach, every issue can be addressed quickly. It is often found a variety of clearly true information and then peppered with captivating narratives using long reviews, including religious doctrine and inserting propaganda in accordance with the author's ideology. For anti-nation state groups, every issue can be fried to spread influence and always offer a caliphate government system as a solution. Meanwhile, suppose you look at and compare it with the syllabus and material learning books on the History of Islamic Culture (SKI). In that case, it is very limited to discussing the caliphate from dynasty to dynasty, the period leading to the next caliphate period. The SKI learning tends to contain more romanticism of the last caliphate's greatness and golden age. Very little explains the shortcomings, depravity, intrigue, seizure of power, and bloodshed among fellow Muslims. It is very different from, for example, the Tarikh Khulafa, which completely reveals everything that happened during the Caliphate.

Students as recipients of information (communicants) have not properly filtered religious information conveyed in online social media. But on the other hand, there is an influential ideological penetration with a closed attitude to follow other media, which tend to be more moderate. In other words, students who are quite intense in following certain media studies will ignore other media that are not familiar (or the language that is often used is not the same in manhaj).

Some religious groups protect or restrict their followers from reading, listening to, or watching any content conveyed by nonsocial media. Although many online media are more scientific, rational, and contextual, these followers are not interested in conveying various arguments and healthier discourses. Thus, it is hoped that the desired religious doctrine will be preserved in followers. Continuous injection of similar information will form followers who are considered istiqamah. They are formed into exclusive students or can be called pre-conservative.

This condition is supported by the sophistication of internet technology today. A social media platform similar to Facebook and Instagram tends to sort its users based on the same segment and group users into likeminded groups. Social media users who have searched (browsed) using certain keywords are more likely to receive similar information on social media. On the respective homepage, similar posts will appear before other information (status or posts). Yasir Alimi (2018: 45) calls it creating echo spaces that strengthen our views.

Anwar Arifin $(2011,68$.) describes the hypodermic needle theory which produces two basic assumptions. First, the recipient (communicant) is helpless when receiving messages from the communicator. Second, the mass media is very powerful, and it can even be said that its power is approaching unseen. The purpose of the two basic assumptions above: First, that the communicant's powerlessness when receiving a message from the communicator shows that the communicator has the convenience of influencing the communicant. From this theory, it can also be understood that the nature of the communicant is very passive in receiving messages from the communicator. And whatever is conveyed by the communicator, especially if it is through the mass media, will have a positive effect (either in the form of a good image, acceptance, or support) on the communicant. Second, all messages communicated through the mass media will be very easy to use to influence the audience.

Continuous exposure to similar religious information influences the mindset and actions of Madrasah Aliyah students. At least this can be seen in changes in some religious practices in students' daily lives. For example, those who no longer want to attend maulid events in the religious tradition, oppose the kalosara event. Their trust in the government is deemed not in accordance with 
sharia, or sympathy for groups against differences, support for HTI and FPI because they are considered firmly against evil, often destroy places of immorality and fight for an Islamic State. Another thing is his refusal or disinterest in scholars who are outside the manhaj he follows.

Students' analytical ability towards information conveyed in online social media is very minimal. A short study that only delivers the arguments one-sidedly and concludes the law of halal-haram is quickly favored compared to the in-depth study pattern usually conveyed by more moderate clerics or ustadz. This also happens in several articles or writings that "must" come from the same manhaj, affecting the student's position.

Students will believe anything conveyed by ustadz with the same manhaj. One example is that students can easily trust Alfian Tanjung's lecture on the rise of the PKI because he is considered partisan. There is no data confirmation process on his explanation. Another thing is about the flat earth theory because it is considered in accordance with the Al-Qur'an which states "the earth is spread out", so any information that corresponds to or supports that information will be immediately accepted.

A person, who adheres to the understanding that the earth is flat, read an article that reviews various theories of inspiration regarding satellite photos. Then, instinctively that person will be very easy to believe because he supports the flat earth theory he believes. Naturally, a positive feeling will grow in him if the opinion or belief he holds is affirmed so that he tends not to care whether the information he receives is correct. It is even very easy to spread the information back. Therefore, it is important to have sufficient knowledge to trace hoax information by utilizing internet facilities to check the facts.

In the context of Kendari City, where there are not many Islamic boarding schools, NU and Muhammadiyah as mass organizations that strongly support the Indonesian nation-state and strengthen religious moderatism in Indonesia do not have a strong enough influence on society. That is why this space is quite easily utilized by salafi groups who tend to be puritanical. There are many variants of the salafi group filling religious discourses in this city. This group has a lot of resources and controls the media. Similar to other cities, moderate groups have come too late to the digital space. In Kendari, since several years ago, anti-NKRI groups such as HTI were quite active in spreading propaganda on online social media. Also, the ICM salafi group has a radio and is quite active in distributing video content for religious lectures on social media. According to Yasir Alimi (2018: 258), more urbanites are affiliated with fundamentalist groups. In this city, none of them are affiliated with pesantren and Kiai, so they tend to look for their Islamic identity with social media and ustadz who may not have adequate scientific capabilities.

The tendency to like that which is instantaneous and fast-paced is also the reason it is easy for urbanites to participate in religious preaching independently in online media. In cyberspace, all content variants are available and can be accessed anytime, anywhere. This instant nature also causes short lecture content that is considered firmly establishing a law on certain religious issues to be more favorable than in-depth study and is considered hesitant to stipulate laws.

The same can be seen in religious articles that are of interest to Madrasah Aliyah students. Short religious articles are preferred over long ones and are considered timeconsuming. The first characteristic can generally be seen by preachers and from various salafi Wahabi sites. Meanwhile, moderate sites such as NU.online, Muhammadiyah, Alif.id, sharia talk, etc., tend to be careful in verifying or enforcing religious issues. In a moderate site, when discussing a problem, there will be a lot of quoting the opinions of the scholars of various schools of thought and more leaving it to the tendency of the people to follow whose opinion, no one is found that easily labels haram, heresy, heretical, hypocritical to the infidel, etc. Online media has now become a battleground for the spread of propaganda and opinion.

\section{CLOSING}

Madrasah Aliyah students are very active in accessing religious preaching content through online social media platforms. The online media that is most accessed and used for 
religious content are Instagram and YouTube in the form of audio-visual videos. The rest are interested in reading status and articles that are considered to the same with their belief. Some students are following several popular preachers who are actively spreading religious content on social media. At first, their interest begins by measuring the popularity of the speech using simple criteria, including the number of followers, views, and shares of many people. The next stage is to measure whether the content is considered the most appropriate with the Al-Qur'an and Hadith or not. They also are not interested in following scholars who are considered contradictory or can be called moderate. From the reading in the online media, some students questioned and challenged the basis of the State, religious traditions, and local traditions, both aimed at their teachers, families, and relatives. In daily behavior, there is a positive side that students are more diligent in worshiping in the Mosque.

The school and teachers have tried to harmonize the religious understanding of students that they get in online media, including through religious moderation programs, introduction and interaction with different religions, and rejection of closed religious understandings. However, it must be admitted that many students' religious practices and understandings are beyond the teacher's observation.

Therefore, the process of religious learning in schools must be reformulated to include moderate and balanced Islamic teachings so that students can be more open to accepting differences. Furthermore, it becomes important to improve students' analytical skills for any information conveyed on social media. Prevention wrong information to be spread can be done by increasing student literacy through the active role of the government, in this case, the Ministry of Religion and the Ministry of National Education, teachers, parents, and communities carrying out systematic and continuous education and taking effective legal action to spread radical propaganda, anti-country, or against those who are anti-diversity.

\section{ACKNOWLEDGEMENTS}

The writers would like to thank the supervisors who guided me in this research. To
Head Office Balai Litbang Agama Makassar for all of supporting for this research. The writers also thank the editorial board of the AlQalam Journal for publishing this article.

\section{REFERENCES}

Alimi, Moh. Yasir. 2018. Mediatisasi Agama, Post-Truth dan Ketahanan Nasional; Sosiologi Agama Era Digital. LKiS: Yogyakarta

Anwar Arifin. 2011 Dakwah Kontemporer. Graha Ilmu: Yogyakarta

APJII. 2019. Survey Nasional Penetrasi Pengguna Internet 2018. Powerpoint Infografis. Asosiasi Pengelola Jaringan Internet Indonesia.

Tim Penyusun Kementerian Agama. 2019. Moderasi Beragama. Jakarta. Badan Litbang dan Diklat Kementerian Agama RI

Eriyanto. 2005. Analisis Wacana Pengantar Analisis Teks Media. Yogyakarta: LKiS.

Hootsuite. "Indonesian Digital Report 2019". Alamat link:

https://andi.link/hootsuite-we-aresocial-indonesian-digital-report-2019/ . Diakses 06 Januari 2020.

KBBI V. 2017. (aplikasi online, pembaruan terakhir 18 Desember 2019). Badan Bahasa, Kementerian Pendidikan dan Kebudayaan Republik Indonesia.

Kurniawan, Agung. 2005. "Transformasi Pelayanan Publik". Yogyakarta: Penerbit Pembaruan

Lupton, Deborah. 2015. "Digital Sociology". New York: Routledge.

McQuail, Denis. 2011. "Teori Komunikasi Massa McQuail”, Edisi 6 Buku 1. Jakarta: Salemba Humanika.

Muslim, A. 2017. Membaca Eksistensi 'Pusat Literasi'Dari Pelosok Negeri: Ironi Pengelolaan Perpustakaan Madrasah Aliyah Konawe Selatan. Penamas, 28(1), 25-42.

Muslim, A. 2019. Curhat Di Balik Laci: Ekspresi Literasi Siswa Di Madrasah Aliyah Pesri Kendari. Al-Qalam, 25(1), 211-224. 
Paisal. 2015. "Pergeseran Faham Keagamaan Mahasiswa IAIN Sultan Qaimuddin Kendari”. Laporan Hasil Penelitian. Balai Litbang Agama Makassar.

Pujileksono, Sugeng. 2015 "Metode penelitian komunikasi kualitatif". Malang: Kelompok Intrans Publishing

Saputra, Muhammad Ali. 2016. "Respon Siswa Muslim Terhadap Radikalisme Agama di KTI". Laporan Hasil Penelitian. Balai Litbang Agama Makassar.
Saputra, Eddy. 2016. "Dampak Sosial Media Terhadap Sikap Keberagamaan Remaja dan Solusiya Melalui Pendidikan Agama Islam,". Diunduh dari jurnal SOSISO-E-KONS, Vol. 8 No. 2 Agustus 2016. Hal. 160-168.

Teguh Prasetyo, Angga. 2014. "Media Sosial dan Perkembangan Aliran Keagamaan Pasca Munculnya Gerakan ISIS”, dalam Jurnal El-Qudwah Lembaga Penelitian dan Pengabdian kepada Masyarakat (LP2M) UIN Maulana Malik Ibrahim Malang edisi 10 tahun 2014. 
